\title{
Small-Animal PET Imaging of Human Epidermal Growth Factor Receptor Type 2 Expression with Site-Specific ${ }^{18}$ F-Labeled Protein Scaffold Molecules
}

\author{
Zhen Cheng ${ }^{1}$, Omayra Padilla De Jesus ${ }^{2}$, Mohammad Namavari ${ }^{1}$, Abhijit De ${ }^{1}$, Jelena Levi ${ }^{1}$, Jack Matt Webster ${ }^{2}$, \\ Rong Zhang ${ }^{2}$, Brian Lee ${ }^{2}$, Faisal A. Syud ${ }^{2}$, and Sanjiv Sam Gambhir ${ }^{1}$ \\ ${ }^{1}$ Molecular Imaging Program at Stanford, Departments of Radiology and Bioengineering, Bio-X Program, Stanford University, \\ Stanford, California; and ${ }^{2}$ Global Research, General Electric Company, Niskayuna, New York
}

Human epidermal growth factor receptor type 2 (HER2) is a wellestablished tumor biomarker that is overexpressed in a wide variety of cancers and that serves as a molecular target for therapeutic intervention. HER2 also serves as a prognostic indicator of patient survival and as a predictive marker of the response to antineoplastic therapy. The development of ${ }^{18} \mathrm{~F}$-labeled biomolecules for PET imaging of HER2 (HER2 PET) is very important because it may provide a powerful tool for the early detection of HER2-positive tumor recurrence and for the monitoring of HER2based tumor treatment. Methods: In this study, anti-HER2 monomeric and dimeric protein scaffold molecules $\left[Z_{\text {HER2:477 }}\right.$ and $\left(Z_{\text {HER2:477 }}\right)_{2}$, respectively] were radiofluorinated at a reasonable radiochemical yield $(13 \%-18 \%)$ by use of site-specific oxime chemistry. The resulting radiofluorinated protein scaffold molecules were then evaluated as potential molecular probes for small-animal HER2 PET by use of a SKOV3 tumor-bearing mouse model. Results: The 4-18F-fluorobenzaldehyde conjugated aminooxy-protein scaffolds $\left[{ }^{18} \mathrm{~F}-\mathrm{N}\right.$-(4-fluorobenzylidene)oxime (FBO)- $Z_{\text {HER2:477 }}$ and ${ }^{18}$ F-FBO- $\left(Z_{\text {HER2:477 }}\right)_{2}$ ] both displayed specific HER2-binding ability in vitro. Biodistribution and small-animal PET imaging studies further revealed that ${ }^{18} \mathrm{~F}-\mathrm{FBO}-\mathrm{Z}_{\mathrm{HER} 2: 477}$ showed rapid and high SKOV3 tumor accumulation and quick clearance from normal tissues, whereas ${ }^{18} \mathrm{~F}-\mathrm{FBO}-\left(\mathrm{Z}_{\text {HER2:477 }}\right)_{2}$ showed poor in vivo performance (low tumor uptake and tumorto-normal tissue ratios). The specificity of ${ }^{18} \mathrm{~F}-\mathrm{FBO}-\mathrm{Z}_{\mathrm{HER} 2: 477}$ for SKOV3 tumors was confirmed by its lower uptake on pretreatment of tumor-bearing mice with the HER2-targeting agents $Z_{\text {HER2 }}$ and trastuzumab. Moreover, small-animal PET imaging studies revealed that ${ }^{18} \mathrm{~F}-\mathrm{FBO}-\mathrm{Z}_{\mathrm{HER} 2: 477}$ produced higher-quality tumor imaging than ${ }^{18} \mathrm{~F}-\mathrm{FBO}-\left(\mathrm{Z}_{\mathrm{HER} 2: 477}\right)_{2} \cdot{ }^{18} \mathrm{~F}-\mathrm{FBO}-\mathrm{Z}_{\text {HER2:477 }}$ could clearly identify HER2-positive tumors with good contrast. Conclusion: Overall, these data demonstrate that ${ }^{18} \mathrm{~F}-\mathrm{FBO}-\mathrm{Z}_{\mathrm{HER} 2: 477}$ is a promising PET probe for imaging HER2 expression in living mice. It has a high potential for translation to clinical applications. The radiofluorination method developed can also be used as a general

Received Sep. 14, 2007; revision accepted Jan. 22, 2008.

For correspondence or reprints contact: Sanjiv Sam Gambhir, Molecular Imaging Program at Stanford, Departments of Radiology and Bioengineering, Bio-X Program, Clark Center, E-150, 318 Campus Dr., Stanford University, Stanford, CA 94305.

E-mail: sgambhir@stanford.edu

COPYRIGHT @ 2008 by the Society of Nuclear Medicine, Inc. strategy for the site-specific labeling of other proteins with ${ }^{18} \mathrm{~F}$. The protein scaffold molecules used here are attractive for the further development of PET probes for other molecular targets.

Key Words: Affibody; HER2; PET; imaging; ${ }^{18} \mathrm{~F}$

J Nucl Med 2008; 49:804-813

DOI: 10.2967/jnumed.107.047381

$\mathbf{H}$ uman epidermal growth factor receptor type 2 (HER2), a transmembrane protein and a member of the erbB family of receptor tyrosine kinase proteins, is a wellestablished tumor biomarker that is overexpressed in a wide variety of cancers, including breast, ovarian, lung, gastric, and oral cancers $(1,2)$. HER2 amplification and activation promote tumor cell proliferation, growth, migration, adhesion, and invasiveness. HER2 upregulation also contributes to the resistance of cancer cells to apoptosis, thereby leading to an improvement in the survival of cancer cells. It has been found that HER2 overexpression is usually associated with high-grade aggressive tumors and a poor prognosis (2). Therefore, HER2 has great value as a molecular target for therapeutic intervention, as a prognostic indicator of patient survival, and as a predictive marker of the response to antineoplastic therapy.

Over the last decade, noninvasive molecular imaging of HER2 expression with various imaging modalities has been extensively studied; these modalities include radionuclide imaging with PET and SPECT (3-15), MRI (16), and optical imaging $(17,18)$. PET imaging of HER2 (HER2 PET) is particularly useful because of its high sensitivity, high spatial resolution, strong quantification ability, and great potential for translation to clinical applications. Compared with the fluorescence in situ hybridization (FISH) and immunohistochemistry (IHC) tests currently used in clinical practice for the determination of HER2 status, PET provides a real-time assay of overall tumor HER2 expression in patients; therefore, it is expected to avoid false-negative results, which are 
caused by sampling errors and heterogeneity of expression in biopsied tumor samples. Furthermore, HER2 PET may be very helpful for the identification of HER2 expression in tumors over time, the selection of patients for HER-targeted treatment (such as trastuzumab-based therapy), prediction of the response to therapy, the evaluation of drug efficacy, and many other applications.

Although various HER2 PET techniques have been evaluated with preclinical small-animal tumor models, developing a PET probe for routine clinical use has not yet been successfully achieved, mainly because of the limited availability of HER2-binding ligands to the molecular imaging field. Indeed, the majority of efforts for HER2 imaging agent development have been focused on using HER2-avid antibodies or antibody-derived fragments $(3,4,17,18)$. Unfortunately, the slow tumor targeting and slow normal tissue clearance of antibody-based probes severely hamper their clinical applications. Moreover, the slow pharmacokinetic clearance of antibody-based probes generally leads to the selection of radioisotopes with relatively long half-lives, such as ${ }^{64} \mathrm{Cu}(12.7 \mathrm{~h}),{ }^{86} \mathrm{Y}(14.7$ h), ${ }^{124} \mathrm{I}(4.18 \mathrm{~d})$, and ${ }^{76} \mathrm{Br}(16.0 \mathrm{~h})$, as radiolabels, potentially resulting in elevated radiation doses to patients. The limited availability and high cost of those radioisotopes also become significant problems and hinder the further development of antibody-based HER2 imaging agents.

Recently, molecules that were derived from one of the IgG-binding domains of staphylococcal protein A (Affibody molecules) have received a lot of attention $(5-15,19)$. Affibody molecules are composed of a relatively small engineered protein scaffold with 58 amino acid residues and a 3-helix-bundle scaffold structure. They possess some favorable properties, including ease of preparation, possible production by chemical synthesis, high affinity and specificity, rapid blood clearance, and rapid and good tumor tissue penetration and accumulation. Moreover, Affibody binders against desired targets can be quickly identified and selected by use of phage display technology (20). Thus, Affibody molecules have great potential to become a universal platform for developing imaging or therapeutic agents for various biomarkers.

High-affinity HER2-binding Affibody molecules were obtained by use of phage display technology and affinity maturation $(8,20)$. Subsequently, these proteogenic derivatives were radiolabeled with various radioisotopes, including ${ }^{99 \mathrm{~m}} \mathrm{Tc},{ }^{111 / 114 \mathrm{~m} I n,}{ }^{90} \mathrm{Y},{ }^{177} \mathrm{Lu},{ }^{68} \mathrm{Ga},{ }^{125} \mathrm{I},{ }^{76 / 77 / 82} \mathrm{Br}$, and ${ }^{211} \mathrm{At}(5-15)$, and were evaluated as therapeutic and imaging agents for malignant tumors overexpressing HER2. These studies clearly demonstrated that Affibody molecules are a promising new class of HER2-targeting ligands worthy of further evaluation in the development of PET probes for clinical HER2 imaging.

We hypothesized that Affibody binders would be ideal candidates for developing ${ }^{18} \mathrm{~F}$-labeled PET molecular probes because of their fast tumor-targeting ability, fast pharmacokinetic clearance, and ability to recognize a wide variety of molecular targets. ${ }^{18} \mathrm{~F}$, the most commonly used PET radionuclide, is widely available and has almost ideal imaging properties (half-life: $110 \mathrm{~min}$; emits $\beta^{+}$-particles at an energy of $635 \mathrm{keV}$; 97\% abundant) (21); these features make this radionuclide highly clinically relevant. Our goal is to ultimately apply Affibody-based PET probes for imaging patients. In this study, we developed a method for the site-specific radiofluorination of Affibody molecules, using anti-HER2 Affibody molecules $\left[\mathrm{Z}_{\mathrm{HER} 2: 477}\right.$ and $\left.\left(\mathrm{Z}_{\mathrm{HER} 2: 477}\right)_{2}\right]$ as model proteins. The in vitro and in vivo biologic profiles of these ${ }^{18}$ F-labeled anti-HER2 Affibody molecules were evaluated in cultured SKOV3 cells with high HER2 expression levels and nude mice bearing subcutaneous SKOV3 tumors. Finally, the ability of ${ }^{18} \mathrm{~F}$-labeled $\mathrm{Z}_{\mathrm{HER} 2: 477}$ and $\left(\mathrm{Z}_{\mathrm{HER} 2: 477}\right)_{2}$ to image HER2 expression in living mice was evaluated with small-animal PET.

\section{MATERIALS AND METHODS}

\section{General}

The anti-HER2 imaging agent, Affibody molecule $\mathrm{Z}_{\mathrm{HER} 2: 477}$, and the anti-HER2, unconjugated bivalent Affibody molecule, $\left(\mathrm{Z}_{\mathrm{HER} 2: 477}\right)_{2}$, were purchased from Affibody AB. All of the other general materials and instruments and the synthesis of the bifunctional linker [2-(aminooxy)- $\mathrm{N}$-(2-(2,5-dioxo-2,5-dihydro- ${ }^{1} \mathrm{H}-$ pyrrol1-yl)ethyl)acetamide hydrochloride] (Mal-AO), aminooxy-functionalized Affibody molecules $\left[\mathrm{Z}_{\mathrm{HER} 2: 477}-\mathrm{ONH}_{2}\right.$ and $\left.\left(\mathrm{Z}_{\mathrm{HER} 2: 477}\right)_{2}-\mathrm{ONH}_{2}\right]$, and 4-fluorobenzaldehyde (4-FBA)-conjugated aminooxy-functionalized Affibody molecules [ $N$-(4-fluorobenzylidene)oxime (FBO)$\mathrm{Z}_{\mathrm{HER} 2: 477}$ and FBO- $\left.\left(\mathrm{Z}_{\mathrm{HER} 2: 477}\right)_{2}\right]$, are described in the supplemental materials (available online only at http://jnm.snmjournals.org). The procedures for in vitro analysis of Affibody bioconjugates are also described in the supplemental materials.

\section{Radiosynthesis of ${ }^{18} \mathrm{~F}$-Labeled Affibody Molecules: ${ }^{18} \mathrm{~F}-\mathrm{FBO}-\mathrm{Z}_{\text {HER2:477 }}$ and ${ }^{18} \mathrm{~F}-\mathrm{FBO}-\left(\mathrm{Z}_{\text {HER2:477 }}\right)_{2}$}

The Affibody molecules $\mathrm{Z}_{\mathrm{HER} 2: 477}-\mathrm{ONH}_{2}$ and $\left(\mathrm{Z}_{\mathrm{HER} 2: 477}\right)_{2}-$ $\mathrm{ONH}_{2}$ were radiofluorinated with an ${ }^{18} \mathrm{~F}$-labeled prosthetic group (4- ${ }^{18}$ F-FBA) by use of a slight modification of a procedure reported before (22). $4-{ }^{18} \mathrm{~F}$-FBA was first prepared by use of a GE TRACERlab FX-FN synthetic module (GE Healthcare) (Fig. 1). In brief, non-carrier-added ${ }^{18} \mathrm{~F}^{-}$trapped on a quaternary ammonium anion exchange cartridge (11.1-37 GBq [300-1,000 mCi]) was washed with a solution of $\mathrm{K}_{2} \mathrm{CO}_{3}$ and Kryptofix 2.2.2 (Sigma) in water and acetonitrile. After evaporation of the solution and azeotropic drying of the residue, a solution of a 4-formyl- $N, N, N$ trimethylanilinium triflate precursor (4-6 mg) in dimethyl sulfoxide was added to the reactor, and the mixture was heated for 10 min at $85^{\circ} \mathrm{C}$. Purification of the reaction mixture with a $\mathrm{C}_{18}$ cartridge system afforded the product ${ }^{4-}{ }^{18} \mathrm{~F}-\mathrm{FBA}$ at a $50 \%-70 \%$ radiochemical yield (decay corrected) and an overall synthesis

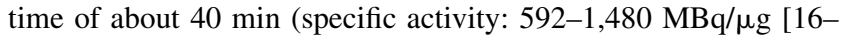
$40 \mathrm{mCi} / \mu \mathrm{g}])$.

Subsequently, $\mathrm{Z}_{\mathrm{HER} 2: 477}-\mathrm{ONH}_{2}$ or $\left(\mathrm{Z}_{\mathrm{HER} 2: 477}\right)_{2}-\mathrm{ONH}_{2}(0.25$ or $0.5 \mathrm{mg}$, respectively, in $100 \mu \mathrm{L}$ of ammonium acetate [pH 4]) (Fig. 1) was incubated with $4{ }^{18}$ F-FBA $(0.185-0.259$ GBq [5-7 $\mathrm{mCi}]$ in $50 \mu \mathrm{L}$ of methanol) at $70^{\circ} \mathrm{C}$ for $15 \mathrm{~min}$. The reaction solution was cooled and purified by use of an analytic highperformance liquid chromatography (HPLC) column (flow rate, $1 \mathrm{~mL} / \mathrm{min})$. For the purification of ${ }^{18} \mathrm{~F}-\mathrm{FBO}-\mathrm{Z}_{\mathrm{HER} 2: 477}$, the mobile 
FIGURE 1. Synthetic schemes for bifunctional linker Mal-AO, $\mathrm{Z}_{\mathrm{HER} 2: 477^{-}}$ $\mathrm{ONH}_{2}, \quad\left(\mathrm{Z}_{\mathrm{HER} 2: 477}\right)_{2}-\mathrm{ONH}_{2},{ }^{18 \mathrm{~F}-\mathrm{FBO}-}$ $\mathrm{Z}_{\mathrm{HER} 2: 477}$, and ${ }^{18} \mathrm{~F}-\mathrm{FBO}-\left(\mathrm{Z}_{\mathrm{HER} 2: 477}\right)_{2}$. Boc $=$ tert-butoxycarbonyl; DMSO = dimethyl sulfoxide; EDC = 1-ethyl-3-(3-dimethylaminopropyl)carbodiimide; HOBT $=N$-hydroxybenzotriazole; $\mathrm{MeOH}=$ methanol; $\mathrm{NH}_{4} \mathrm{OAc}=$ ammonium acetate; PBS $=$ phosphate-buffered saline.

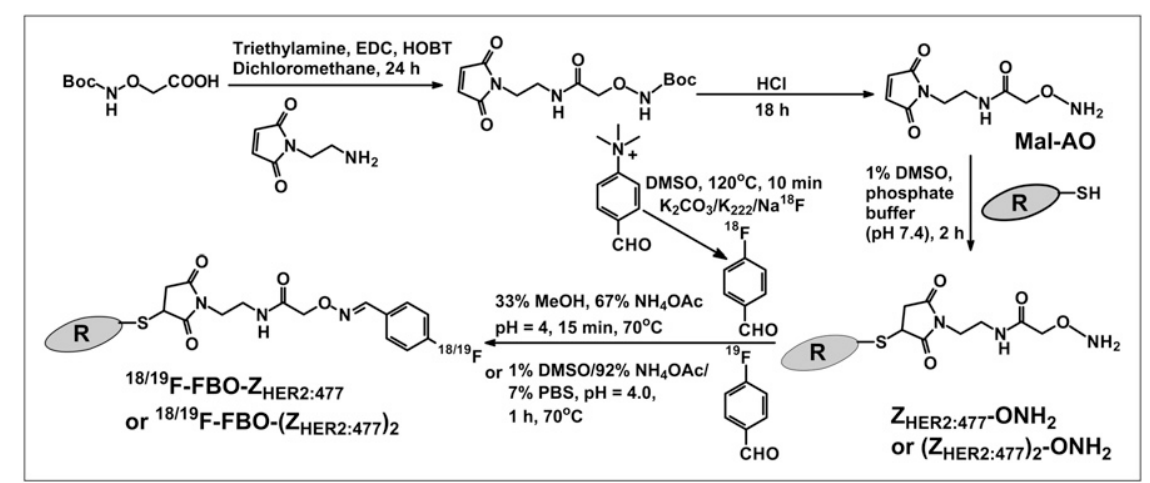

phases were $95 \%$ solvent $\mathrm{A}$ and $5 \%$ solvent $\mathrm{B}$ (0-3 min), $80 \%$ solvent A and $20 \%$ solvent B (at $25 \mathrm{~min}$ ), and then $85 \%$ solvent B and $15 \%$ solvent $A$ (25-36 min); the last solvent composition was maintained for another $3 \mathrm{~min}(36-39 \mathrm{~min})$, and then the solvent composition was returned to the initial composition by $42 \mathrm{~min}$. For the purification of ${ }^{18} \mathrm{~F}-\mathrm{FBO}-\left(\mathrm{Z}_{\mathrm{HER} 2: 477}\right)_{2}$, the mobile phases were $95 \%$ solvent $A$ and $5 \%$ solvent $\mathrm{B}$ ( $0-3 \mathrm{~min}), 35 \%$ solvent $\mathrm{A}$ and $65 \%$ solvent $\mathrm{B}$ (at $30 \mathrm{~min}$ ), and then $85 \%$ solvent $\mathrm{B}$ and $15 \%$ solvent A (33-36 min); the last solvent composition was maintained for another $3 \mathrm{~min}$ (36-39 $\mathrm{min})$, and then the solvent composition was returned to the initial composition by $42 \mathrm{~min}$. The HPLC fractions containing the ${ }^{18}$ F-labeled Affibody molecules were collected, combined, and treated with a rotary evaporator to dry the product. The radiolabeled Affibody molecules were reconstituted in phosphate-buffered saline and passed through a $0.22-\mu \mathrm{m}$ Millipore filter into a sterile vial for in vitro and animal experiments.

\section{Cell Assays}

SKOV3 cells were cultured in RPMI 1640 medium supplemented with $10 \%$ fetal bovine serum and $1 \%$ penicillin-streptomycin (Invitrogen Life Technologies). The cells were maintained in a humidified atmosphere of $5 \% \mathrm{CO}_{2}$ at $37^{\circ} \mathrm{C}$, and the medium was changed every other day. A confluent monolayer was detached with trypsin and dissociated into a single-cell suspension for further cell culturing.

In vitro cell uptake assays for ${ }^{18} \mathrm{~F}-\mathrm{FBO}-\mathrm{Z}_{\mathrm{HER} 2: 477}$ and ${ }^{18} \mathrm{~F}-\mathrm{FBO}-$ $\left(\mathrm{Z}_{\mathrm{HER} 2: 477}\right)_{2}$ were performed with SKOV3 cells as previously described (23). In brief, the cells were used to seed 24-well tissue culture plates at a density of $0.2 \times 10^{6}$ cells per well and were allowed to attach overnight. After a wash with RPMI 1640 medium, the cells were incubated at $37^{\circ} \mathrm{C}$ for $0.5-2 \mathrm{~h}$ with the radioactive probes $(1.11-6.29 \mathrm{kBq}[0.03-0.17 \mu \mathrm{Ci}])$ in $0.5 \mathrm{~mL}$ of medium. Nonspecific binding of the probes to the SKOV3 cells was determined by coincubation with nonradiolabeled Affibody molecules [10 $\mu \mathrm{g}$ of $\left(\mathrm{Z}_{\mathrm{HER} 2: 477}\right)_{2}$ was added to each sample for ${ }^{18} \mathrm{~F}-\mathrm{FBO}-\left(\mathrm{Z}_{\mathrm{HER} 2: 477}\right)_{2}$, for a final concentration of $1.43 \mu \mathrm{M} ; 1 \mu \mathrm{g}$ of $\mathrm{Z}_{\mathrm{HER} 2}$ was added to each sample for ${ }^{18} \mathrm{~F}-\mathrm{FBO}-\mathrm{Z}_{\mathrm{HER} 2: 477}$, for a final concentration of $0.28 \mu \mathrm{M}$ ]. The cells were rinsed 3 times with $0.01 \mathrm{M}$ phosphate-buffered saline ( $\mathrm{pH} 7.4)$ and $0.2 \%$ bovine serum albumin and lysed in $0.5 \mathrm{~mL}$ of $1.0 \mathrm{M} \mathrm{NaOH}$ for $5 \mathrm{~min}$, and the radioactivity of the cells was measured. The protein concentrations of the samples were measured by use of the Bradford assay (Bio-Rad). All of the data were analyzed with the ORIGIN6.0 computer program (Microcal Software Inc.).

\section{Biodistribution Studies}

All animal studies were performed in compliance with federal and local institutional rules for animal experimentation. Approximately $10^{6}$ SKOV 3 cells suspended in Matrigel (BD Biosciences) were implanted subcutaneously in the flanks of nude mice. Tumors were allowed to grow to a size of 500-750 mg (2-3 wk), and then the tumor-bearing mice were subjected to in vivo biodistribution and imaging studies.

For biodistribution studies, SKOV 3 tumor-bearing mice $(n=3$ for each group) were injected with ${ }^{18} \mathrm{~F}-\mathrm{FBO}-\mathrm{Z}_{\mathrm{HER} 2: 477}(0.37-1.11 \mathrm{MBq}$ [10-30 $\mu \mathrm{Ci}] ; 0.125-0.375 \mu \mathrm{g})$ or ${ }^{18} \mathrm{~F}-\mathrm{FBO}-\left(\mathrm{Z}_{\mathrm{HER} 2: 477}\right)_{2}(0.74-1.665$ MBq [20-45 $\mu \mathrm{Ci}$ ]; $0.5-1.125 \mu \mathrm{g}$ ) via the tail vein and sacrificed at various time points from $30 \mathrm{~min}$ to $3 \mathrm{~h}$ after injection. Tumor and normal tissues of interest were removed and weighed, and their radioactivity was measured with a $\gamma$-counter. The radioactivity uptake in the tumor and normal tissues was expressed as a percentage of the injected radioactive dose per gram of tissue (\% ID $/ \mathrm{g})$. For testing of the in vivo HER2-targeting specificity of ${ }^{18} \mathrm{~F}-\mathrm{FBO}-\mathrm{Z}_{\mathrm{HER} 2}$, nude mice bearing SKOV 3 tumors ( $n=3$ for each group) were treated with either $500 \mu \mathrm{g}$ of trastuzumab (tail vein injection, $72 \mathrm{~h}$ before radiolabeled probe injection) or $300 \mu \mathrm{g}$ of $\mathrm{Z}_{\mathrm{HER} 2: 477}$ (tail vein injection, $1 \mathrm{~h}$ before radiolabeled probe injection). The mice were injected with ${ }^{18} \mathrm{~F}-\mathrm{FBO}-\mathrm{Z}_{\mathrm{HER} 2: 477}$, and biodistribution at $1 \mathrm{~h}$ after injection was examined.

\section{Small-Animal PET Imaging}

PET of tumor-bearing mice was performed by use of a microPET R4 rodent-model scanner (Siemens Medical Solutions). Mice bearing SKOV3 tumors were injected with ${ }^{18} \mathrm{~F}-\mathrm{FBO}-\mathrm{Z}_{\mathrm{HER} 2: 477}$ $(0.444-0.814 \mathrm{MBq}[12-22 \mu \mathrm{Ci}] ; 0.15-0.275 \mu \mathrm{g})$ or ${ }^{18} \mathrm{~F}-\mathrm{FBO}-$ $\left(\mathrm{Z}_{\mathrm{HER} 2: 477}\right)_{2}(1.85-2.035 \mathrm{MBq}[50-55 \mu \mathrm{Ci}] ; 1.25-1.375 \mu \mathrm{g})$ via the tail vein. At various times after injection $(0.5$ and $1 \mathrm{~h})$, the mice were anesthetized with $2 \%$ isoflurane and placed in the prone position and near the center of the field of view of the scanner. Static scans $(5 \mathrm{~min})$ were obtained, and the images were reconstructed by use of a 2-dimensional ordered-subsets expectation maximization algorithm. No background correction was performed. Regions of interest (ROIs; 5 pixels for coronal and transaxial slices) were drawn over the tumors on decay-corrected whole-body coronal images. The maximum counts per pixel per minute were obtained from the ROIs and converted to counts per milliliter per minute by use of a calibration constant. On the basis of the assumption of a tissue density of $1 \mathrm{~g} / \mathrm{mL}$, the ROIs were converted to counts per gram per minute. Image ROI-derived $\%$ ID/g values were determined by dividing counts per gram per minute by injected dose. No attenuation correction was performed. 


\section{Statistical Methods}

Statistical analysis was performed by use of the Student $t$ test for unpaired data. A $95 \%$ confidence level was chosen to determine the significance between groups, with $P$ values of less than 0.05 indicating significant differences.

\section{RESULTS}

\section{Chemistry and Radiochemistry}

A distal C-terminal cysteine residue in the engineered anti-HER2 Affibody molecules [ $\mathrm{Z}_{\mathrm{HER} 2: 477}$ and $\left.\left(\mathrm{Z}_{\mathrm{HER} 2: 477}\right)_{2}\right]$ provides a thiol moiety that can be used for site-specific modification of the proteins. A bifunctional linker (Mal-AO) consisting of 2 orthogonal groups, a thiol-reactive maleimide group for conjugation to the engineered cysteine and an ${ }^{18 / 19}$ F-aldehyde-reactive aminooxy group, was synthesized. This linker was prepared by reacting $N$-(2-aminoethyl) malemide with 2-(tert-butoxycarbonylaminooxy)acetic acid under carbodiimide-mediated coupling conditions, yielding the protected form of the linker. The aminooxy group was deprotected by acid cleavage of the tert-butoxycarbonyl group to yield the final product at a quantitative yield (Fig. 1).

The monomeric and dimeric Affibody molecules $\left[\mathrm{Z}_{\mathrm{HER} 2: 477}\right.$ and $\left(\mathrm{Z}_{\mathrm{HER} 2: 477}\right)_{2}$, respectively] were selectively conjugated to the maleimide-aminooxy linker, with quantitative coupling yields. For both constructs, the reactions were completed in $2 \mathrm{~h}$. The monomeric and dimeric aminooxy conjugates $\left[\mathrm{Z}_{\mathrm{HER} 2: 477}-\mathrm{ONH}_{2}\right.$ and $\left(\mathrm{Z}_{\mathrm{HER} 2: 477}\right)_{2}-\mathrm{ONH}_{2}$, respectively] were easily purified by dialysis, with recovery yields of $82 \%$ and $79 \%$, respectively. Electrospray ionization-mass spectrometry (ESI-MS) analysis of the final products (purity of $>95 \%$, as determined by HPLC analysis) confirmed the absence of starting material, and only the products expected, with molecular masses of 6,962.58 $\mathrm{Da}$ and 14,431.45 $\mathrm{Da}$, were obtained for the monomeric and dimeric constructs, respectively [calculated molecular weights (MWs) for constructs $\mathrm{Z}_{\mathrm{HER} 2: 477}-\mathrm{ONH}_{2}$ and $\left(\mathrm{Z}_{\mathrm{HER} 2: 477}\right)_{2}-\mathrm{ONH}_{2}$ were $6,963.55$ and 14,431.26, respectively]. The aminooxy-functionalized Affibody molecules were reacted with 4-FBA to prepare nonradioactive FBO- $\mathrm{Z}_{\mathrm{HER} 2: 477}$ and FBO- $\left(\mathrm{Z}_{\mathrm{HER} 2: 477}\right)_{2}$ as standard compounds. For both preparations, recovery yields were typically 70\%-90\%, and coupling yields were quantitatively determined by ESI-MS characterization (i.e., no detected starting material). Purified FBO-Z $\mathrm{HER}_{\mathrm{HE}: 477}$ and FBO$\left(\mathrm{Z}_{\mathrm{HER} 2: 477}\right)_{2}$ were characterized by ESI-MS. The measured MWs for both constructs were consistent with the expected MWs [for FBO-Z $Z_{\mathrm{HER}}$, calculated MW = 7,069.64 and found $\mathrm{MW}=7,068.94$; for $\mathrm{FBO}-\left(\mathrm{Z}_{\mathrm{HER} 2}\right)_{2}$, calculated $\mathrm{MW}=$ 14,537.67 and found $\mathrm{MW}=14,538.59]$.

Similarly, 4- ${ }^{18}$ F-FBA was prepared and conjugated to the Affibody molecules $\left[\mathrm{Z}_{\mathrm{HER} 2: 477}-\mathrm{ONH}_{2}\right.$ and $\left(\mathrm{Z}_{\mathrm{HER} 2: 477}\right)_{2^{-}}$ $\mathrm{ONH}_{2}$ ] (coupling yields: $30 \%-40 \%$ ). Under the HPLC conditions used, the retention times of ${ }^{18} \mathrm{~F}-\mathrm{FBO}-\mathrm{Z}_{\mathrm{HER} 2}$ and ${ }^{18} \mathrm{~F}-\mathrm{FBO}-\left(\mathrm{Z}_{\mathrm{HER} 2: 477}\right)_{2}$ were found to be 33.6 and 29.0 min, respectively. The HPLC radiochromatogram of purified ${ }^{18} \mathrm{~F}-\mathrm{FBO}-\mathrm{Z}_{\mathrm{HER} 2: 477}$ is shown in Figure 2. Both products were found to be greater than $95 \%$ radiochemically and

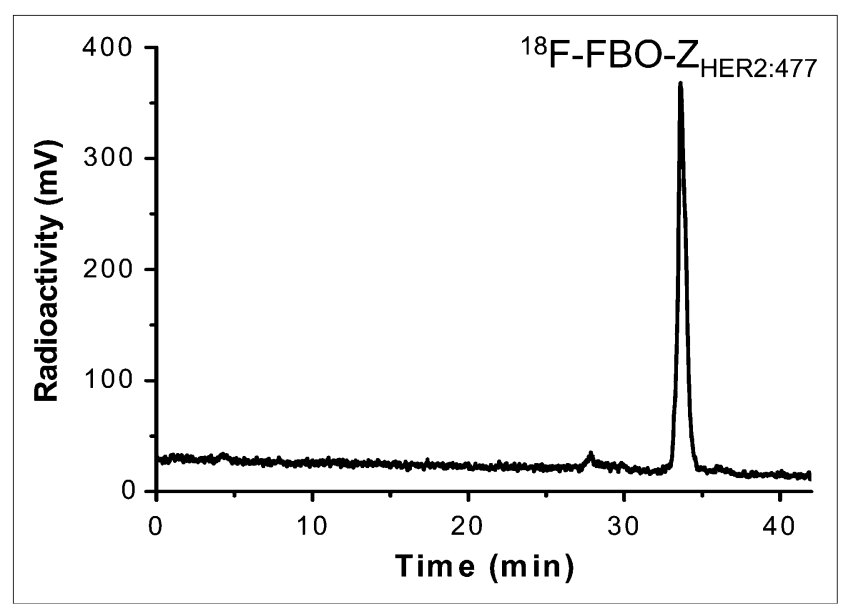

FIGURE 2. HPLC radiochromatogram of purified ${ }^{18} \mathrm{~F}-\mathrm{FBO}-$ Z HER2:477.

chemically pure, as determined by analytic HPLC. The overall radiochemical yield ranged from $13 \%$ to $18 \%$ (end of synthesis; corrected for decay), and the specific activities were 10.4-20.8 MBq/nmol (20-40 $\mu \mathrm{Ci} / \mu \mathrm{g})$ and 13.0-20.7 $\mathrm{MBq} / \mathrm{nmol}(50-80 \mu \mathrm{Ci} / \mu \mathrm{g})$ for the $14-\mathrm{kDa}$ and $7-\mathrm{kDa}$ Affibody bioconjugates, respectively. The total time needed for the synthesis of the ${ }^{18} \mathrm{~F}$-labeled Affibody molecules was about $100 \mathrm{~min}$.

\section{HER2-Binding Affinities of Affibody Bioconjugates}

The binding affinities of the various anti-HER2 Affibody constructs were evaluated in vitro by surface plasmon resonance. The sensorgrams for $\mathrm{Z}_{\mathrm{HER} 2: 477}$ and FBO-

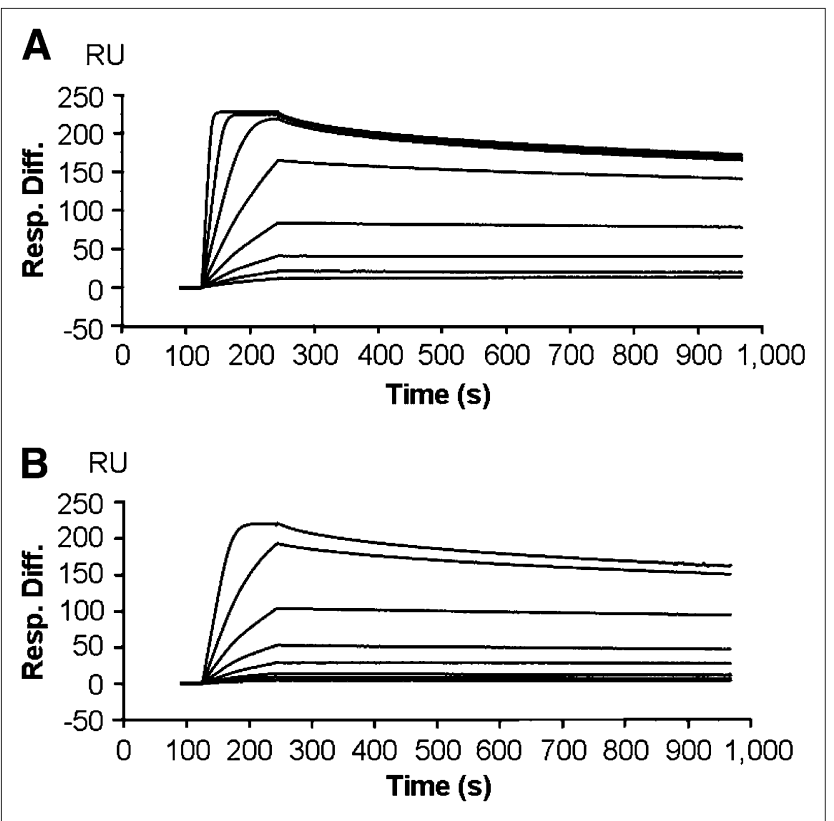

FIGURE 3. Biosensor binding studies of $Z_{\text {HER2:477 }}(A)$ and FBO- $\left(Z_{\text {HER2:477 }}\right)_{2}(B)$. Sensorgrams were obtained after injection of various concentrations of purified Affibody molecules onto sensor chip flow cell surface containing amine-coupled FcHER2 chimeric protein. Resp. Diff. = response difference. 
$\left(\mathrm{Z}_{\mathrm{HER} 2: 477}\right)_{2}$ are shown in Figure 3. The binding affinities of $\mathrm{Z}_{\mathrm{HER} 2: 477}-\mathrm{ONH}_{2}, \mathrm{FBO}-\mathrm{Z}_{\mathrm{HER} 2: 477},\left(\mathrm{Z}_{\mathrm{HER} 2: 477}\right)_{2}-\mathrm{ONH}_{2}$, and FBO- $\left(Z_{\mathrm{HER} 2: 477}\right)_{2}$ were $400,430,180$, and $200 \mathrm{pM}$, respectively. In general, the binding affinity of $\mathrm{Z}_{\mathrm{HER} 2: 477}$ was slightly lower than the binding affinity of the dimeric construct, $\left(\mathrm{Z}_{\mathrm{HER} 2: 477}\right)_{2}$, but was still in the picomolar range. In addition, conjugation of a small molecule like 4-FBA to the Affibody had a minor effect on the affinity of the precursor, arguably considered nonsignificant. An advantageous combination of the properties of these molecules is their very fast "on rate," with association constants in the range of $10^{5}-10^{6}$ for the FBO monomer and the FBO dimer (association time is over $2 \mathrm{~min}$ ), and their very slow "off rate," with dissociation constants in the range of $10^{-4}$ $10^{-5}$ (disassociation time is over $15 \mathrm{~min}$ ), close to the sensitivity limits of the surface plasmon resonance assay.

\section{In Vitro Cell Assays of Affibody Bioconjugates}

Tumor cell line SKOV3, with a high level of HER2 expression (Abhijit De, unpublished data, January 2007), was used for evaluation of the HER2-targeting ability of ${ }^{18} \mathrm{~F}$ labeled Affibody molecules. Levels of cell uptake of ${ }^{18} \mathrm{~F}$ FBO- $\mathrm{Z}_{\mathrm{HER} 2: 477}$ and ${ }^{18} \mathrm{~F}-\mathrm{FBO}-\left(\mathrm{Z}_{\mathrm{HER} 2: 477}\right)_{2}$ at $37^{\circ} \mathrm{C}$ over a 2 -h incubation period are shown in Figures $4 \mathrm{~A}$ and $4 \mathrm{~B}$, respectively. ${ }^{18} \mathrm{~F}-\mathrm{FBO}-\mathrm{Z}_{\mathrm{HER} 2: 477}$ quickly accumulated in SKOV3 cells and reached a value of 0.00476 (cell counts per minute $[\mathrm{cpm}] /$ medium $\mathrm{cpm} / \mu \mathrm{g}$ of protein $/ \mu \mathrm{L}$ ) at $0.5 \mathrm{~h}$. The uptake was maintained at almost the same level until $2 \mathrm{~h}$. A similar cell uptake pattern was observed for ${ }^{18} \mathrm{~F}-\mathrm{FBO}-$ $\left(\mathrm{Z}_{\mathrm{HER} 2: 477}\right)_{2}$, but it showed a level of uptake 3-fold higher than that of the monomeric Affibody at $0.5 \mathrm{~h}$ : 0.01447 (cell $\mathrm{cpm} /$ medium $\mathrm{cpm} / \mu \mathrm{g}$ of protein $/ \mu \mathrm{L}$ ). When both probes were incubated with large excesses of nonradioactive Affibody molecules, their levels of uptake in SKOV3 cells were inhibited significantly $(P<0.05)$ at all incubation time points. For example, uptake values of only $0.00329 \pm$ 0.00027 (mean \pm SD) and $0.00623 \pm 0.00046$ at $0.5 \mathrm{~h}$ of incubation were observed for ${ }^{18} \mathrm{~F}-\mathrm{FBO}-\mathrm{Z}_{\mathrm{HER} 2: 477}$ and ${ }^{18} \mathrm{~F}-$ FBO- $\left(\mathrm{Z}_{\mathrm{HER} 2: 477}\right)_{2}$, respectively. Overall, these results strongly suggested the HER2-binding specificity of ${ }^{18} \mathrm{~F}$ FBO-Z ${ }_{\text {HER 2:477 }}$ and ${ }^{18}$ F-FBO- $\left(\mathrm{Z}_{\text {HER2:477 }}\right)_{2}$.

\section{In Vivo Biodistribution Studies}

The in vivo biodistribution of ${ }^{18} \mathrm{~F}-\mathrm{FBO}-\mathrm{Z}_{\mathrm{HER} 2: 477}$ and ${ }^{18} \mathrm{~F}-\mathrm{FBO}-\left(\mathrm{Z}_{\mathrm{HER} 2: 477}\right)_{2}$ was examined by use of a SKOV3 human ovarian tumor-bearing mouse model. The biodistributions of ${ }^{18} \mathrm{~F}-\mathrm{FBO}-\mathrm{Z}_{\mathrm{HER} 2: 477}$ at $0.5,1$, and $3 \mathrm{~h}$ and of ${ }^{18} \mathrm{~F}-$ FBO- $\left(\mathrm{Z}_{\mathrm{HER} 2: 477}\right)_{2}$ at $0.5,1$, and $2.7 \mathrm{~h}$ are shown in Figure 5. For ${ }^{18} \mathrm{~F}-\mathrm{FBO}-\mathrm{Z}_{\mathrm{HER} 2: 477}$, rapid and high levels of radioactivity accumulation in the HER2-overexpressing SKOV3 tumors were observed at early time points $(4.77 \pm 0.78 \% \mathrm{ID} / \mathrm{g}$ at $0.5 \mathrm{~h}$ after injection). Tumor uptake was slightly reduced, to $3.61 \pm 0.29 \% \mathrm{ID} / \mathrm{g}$, at $3 \mathrm{~h}$ after injection (Fig. 5A). However, the uptake of ${ }^{18} \mathrm{~F}-\mathrm{FBO}-\left(\mathrm{Z}_{\mathrm{HER} 2: 477}\right)_{2}$ in SKOV3 tumors measured only $2.03 \pm 0.31$ and $1.08 \pm 0.15 \% \mathrm{ID} / \mathrm{g}$ at 0.5 and $2.7 \mathrm{~h}$ after injection, respectively; these values were significantly lower than the values for the ${ }^{18} \mathrm{~F}$-labeled monomeric construct $(P<0.05)$ (Fig. 5D).

Both ${ }^{18} \mathrm{~F}$-labeled Affibody bioconjugates displayed relatively rapid blood clearance; blood uptake values of $1.50 \pm$ 0.35 and $1.56 \pm 0.29 \% \mathrm{ID} / \mathrm{g}$ were observed at $1 \mathrm{~h}$ after injection for ${ }^{18} \mathrm{~F}-\mathrm{FBO}-\mathrm{Z}_{\mathrm{HER} 2: 477}$ and ${ }^{18} \mathrm{~F}-\mathrm{FBO}-\left(\mathrm{Z}_{\mathrm{HER} 2: 477}\right)_{2}$, respectively. However, at $0.5 \mathrm{~h}$ after injection, the ${ }^{18} \mathrm{~F}$-labeled dimeric construct exhibited a higher level of blood uptake than the monomeric construct $(3.81 \pm 0.50$ and $1.97 \pm$ $0.24 \% \mathrm{ID} / \mathrm{g}$, respectively; $P<0.05)$. Moreover, ${ }^{18} \mathrm{~F}-\mathrm{FBO}-$ $\left(\mathrm{Z}_{\mathrm{HER} 2: 477}\right)_{2}$ also displayed a significantly higher level of muscle uptake than ${ }^{18} \mathrm{~F}-\mathrm{FBO}-\mathrm{Z}_{\mathrm{HER} 2: 477}$ at $0.5 \mathrm{~h}$ after injection but displayed similar levels of uptake at later time points (Figs. 5A and 5D). Both radiolabeled proteins displayed high levels of renal uptake at early time points (e.g., $0.5 \mathrm{~h}$ after injection; over $20 \% \mathrm{ID} / \mathrm{g}$ ) but moderate levels of uptake at later time points (Figs. 5B and 5E). The monomeric construct also demonstrated a higher level of radioactivity accumulation in the kidneys than the dimeric construct $(7.37 \pm 0.85$ and $2.08 \pm 0.45 \% \mathrm{ID} / \mathrm{g}$ at 3 and $2.7 \mathrm{~h}$ after injection, respectively; $P<0.05)$. ${ }^{18} \mathrm{~F}-\mathrm{FBO}-\left(\mathrm{Z}_{\mathrm{HER} 2: 477}\right)_{2}$ showed a level of liver uptake about 2 -fold higher than that of ${ }^{18} \mathrm{~F}-\mathrm{FBO}-$ $\mathrm{Z}_{\mathrm{HER} 2: 477}$ at $0.5 \mathrm{~h}$ after injection and showed a similar level at $1 \mathrm{~h}$ after injection. These data clearly suggested that ${ }^{18} \mathrm{~F}$ labeled dimeric and monomeric Affibody constructs were cleared through the hepatobiliary, renal, and urinary systems. Importantly, it was found that ${ }^{18} \mathrm{~F}-\mathrm{FBO}-\mathrm{Z}_{\mathrm{HER} 2: 477}$ showed
FIGURE 4. Uptake of ${ }^{18} \mathrm{~F}-\mathrm{FBO}-$ $\mathrm{Z}_{\text {HER2:477 }}$ (A) and ${ }^{18} \mathrm{~F}-\mathrm{FBO}-\left(\mathrm{Z}_{\text {HER2:477 }}\right)_{2}$ (B) in SKOV3 tumors over time at $37^{\circ} \mathrm{C}$ in presence or absence of nonradioactive Affibody molecules. All results, expressed as percentage of activity, are mean of triplicate measurements \pm SD.

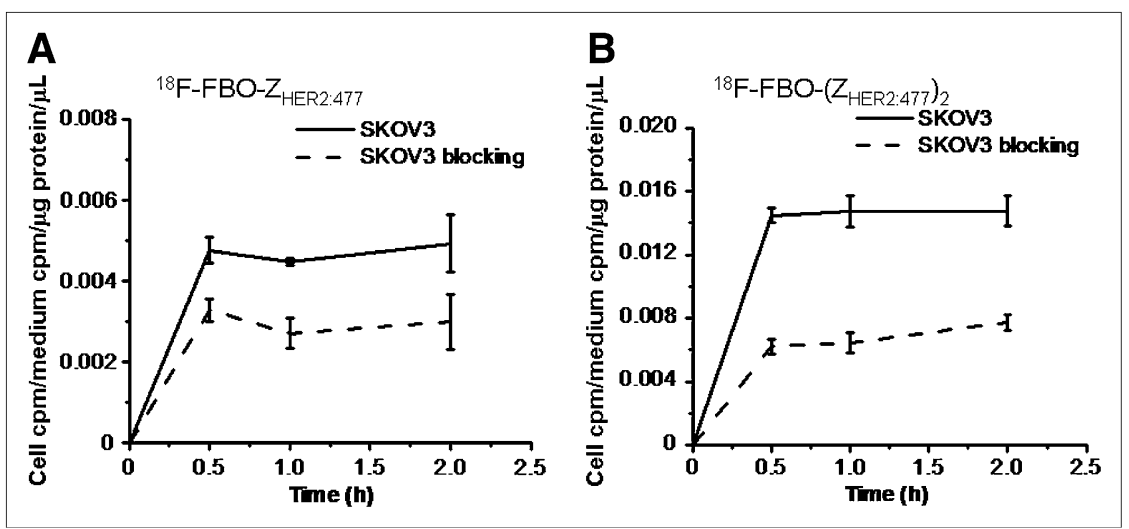




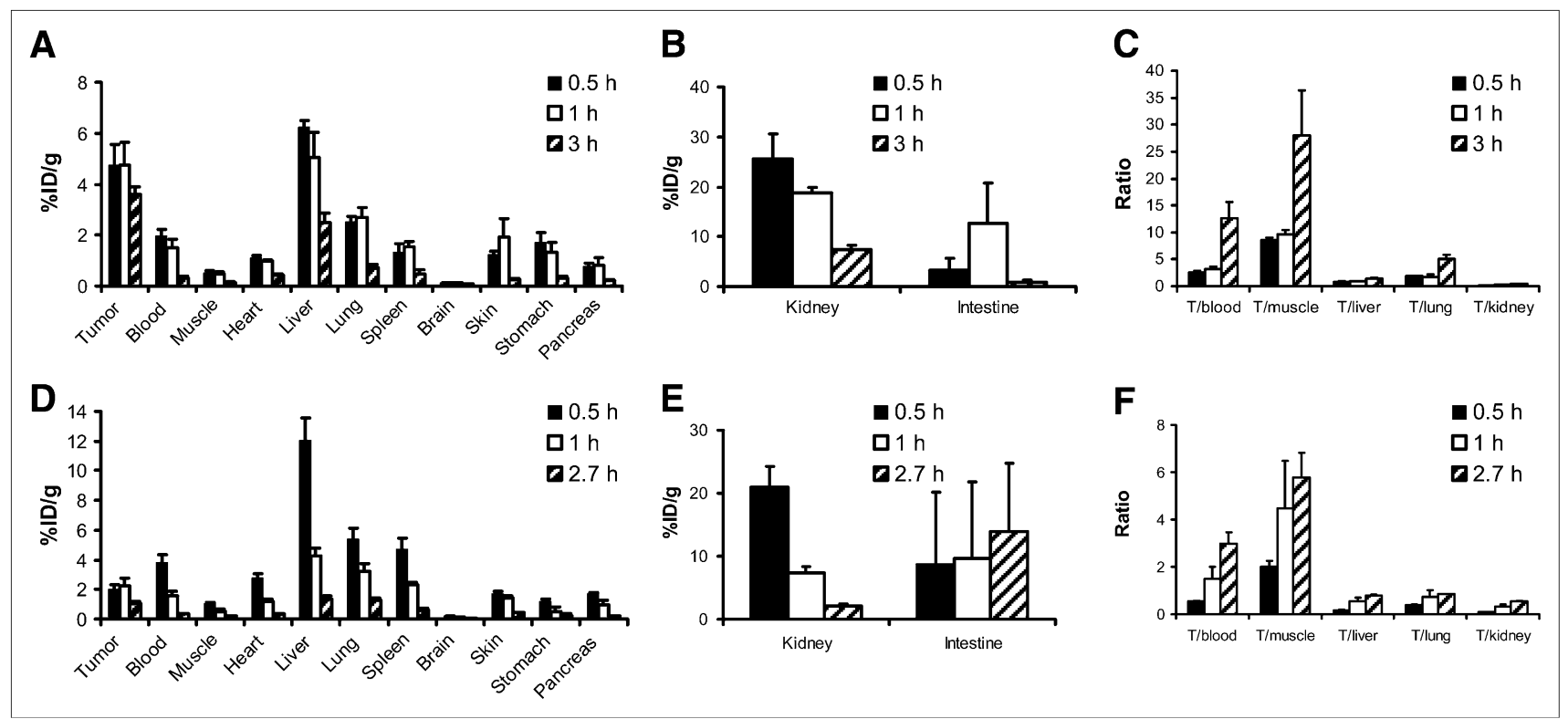

FIGURE 5. Biodistribution results $(A, B, D$, and $E)$ and tumor-to-normal tissue ratios $(C$ and $F)$ for ${ }^{18} F-F B O-Z_{\text {HER2:477 }}(A, B$, and $C)$ and ${ }^{18} \mathrm{~F}-\mathrm{FBO}-\left(\mathrm{Z}_{\mathrm{HER} 2: 477}\right)_{2}(\mathrm{D}, \mathrm{E}$, and $\mathrm{F})$ in nude mice bearing subcutaneously xenotransplanted SKOV3 tumors (human ovarian cancer) $(T)$. Data are expressed as \%ID/g at various times after intravenous injection of ${ }^{18} \mathrm{~F}-\mathrm{FBO}-\mathrm{Z}_{\mathrm{HER} 2: 477}(0.37-1.11 \mathrm{MBq}[10-30$ $\mu \mathrm{Ci}])$ or ${ }^{18} \mathrm{~F}-\mathrm{FBO}-\left(\mathrm{Z}_{\mathrm{HER} 2: 477}\right)_{2}(0.74-1.67 \mathrm{MBq}[20-45 \mu \mathrm{Ci}])\left(n=3\right.$ for each group). ${ }^{18} \mathrm{~F}-\mathrm{FBO}-\mathrm{Z}_{\mathrm{HER} 2: 477}$ showed significantly higher uptake in SKOV3 tumors than ${ }^{18} \mathrm{~F}-\mathrm{FBO}-\left(\mathrm{Z}_{\mathrm{HER} 2: 477}\right)_{2}(P<0.05)$.

significantly higher SKOV3 tumor-to-normal tissue (blood, muscle, liver, and lung) ratios than ${ }^{18} \mathrm{~F}-\mathrm{FBO}-\left(\mathrm{Z}_{\mathrm{HER} 2: 477}\right)_{2}$ at all time points investigated (Figs. 5C and 5F). At $3 \mathrm{~h}$ after injection, the tumor-to-blood and tumor-to-muscle ratios of ${ }^{18} \mathrm{~F}_{-F B O} \mathrm{Z}_{\mathrm{HER} 2: 477}$ were $12.72 \pm 2.94$ and $28.03 \pm 8.28$, respectively.

Because ${ }^{18} \mathrm{~F}-\mathrm{FBO}-\mathrm{Z}_{\mathrm{HER} 2: 477}$ demonstrated high levels of tumor accumulation and favorable pharmacokinetic properties, its in vivo tumor-targeting specificity was further evaluated. It was found that the pretreatment of SKOV3 tumor-bearing mice with $\mathrm{Z}_{\mathrm{HER} 2: 477}$ specifically reduced the SKOV3 tumor uptake of ${ }^{18} \mathrm{~F}-\mathrm{FBO}-\mathrm{Z}_{\mathrm{HER} 2: 477}$ to about $36 \%$ of the corresponding control tumor uptake $(4.77 \pm 0.88$ and $1.73 \pm 0.37 \% \mathrm{ID} / \mathrm{g}$, respectively; $P<0.05$ ). However, no significant difference was observed for uptake in all of the other normal tissues (Fig. 6A). Similarly, the pretreatment of SKOV3 tumor-bearing mice with a HER2-binding protein, trastuzumab (500 $\mu \mathrm{g}$ each), for $72 \mathrm{~h}$ also specifically inhibited the uptake of ${ }^{18} \mathrm{~F}-\mathrm{FBO}-\mathrm{Z}_{\mathrm{HER} 2: 477}$, to about $47 \%$ of the control tumor uptake $(4.77 \pm 0.88$ and $2.25 \pm$ $0.49 \% \mathrm{ID} / \mathrm{g}$, respectively; $P<0.05$ ), but did not alter its accumulation in most of the other normal organs, except for the kidneys (Fig. 6A). Consequently, the SKOV3 tumor-tonormal tissue ratios were all significantly reduced by $\mathrm{Z}_{\mathrm{HER} 2}$ and trastuzumab treatments $(P<0.05)$ (Fig. 6B).

\section{Small-Animal PET Imaging}

Decay-corrected coronal (top row) and transaxial (bottom row) small-animal PET images of a SKOV3 tumor-bearing mouse at $0.5,1,2$, and $4 \mathrm{~h}$ after tail vein injection of ${ }^{18} \mathrm{~F}-$ FBO-Z $\mathrm{HER}_{\mathrm{HE}: 477}$ or ${ }^{18} \mathrm{~F}-\mathrm{FBO}-\left(\mathrm{Z}_{\mathrm{HER} 2: 477}\right)_{2}$ are shown in Fig- ures 7A and 7B, respectively. For ${ }^{18} \mathrm{~F}-\mathrm{FBO}-\left(\mathrm{Z}_{\mathrm{HER} 2: 477}\right)_{2}$, the SKOV3 tumor was visible, especially at later time points, but with low tumor-to-background contrast. For ${ }^{18} \mathrm{~F}-\mathrm{FBO}-$ $\mathrm{Z}_{\mathrm{HER} 2: 477}$, the SKOV3 tumor was clearly visualized, with much better tumor-to-background contrast, at $0.5-4 \mathrm{~h}$ after injection. Also observed were high levels of activity accumulation in the kidneys and part of the gastrointestinal tract for both tracers. Quantification of activity accumulation in the SKOV3 tumor and in the contralateral muscle tissue showed that ${ }^{18} \mathrm{~F}-\mathrm{FBO}-\mathrm{Z}_{\mathrm{HER} 2: 477}$ had about 2-fold-higher tumor uptake but lower muscle uptake than ${ }^{18} \mathrm{~F}-\mathrm{FBO}-$ $\left(\mathrm{Z}_{\mathrm{HER} 2: 477}\right)_{2}$ at $0.5-4 \mathrm{~h}$. The absolute tumor and muscle uptake values (in \%ID/g) obtained from PET image data were consistent with the findings obtained in the biodistribution studies.

\section{DISCUSSION}

The development of PET molecular probes is an important area of molecular imaging that also represents a great challenge, as evidenced by the fact that only a small number of PET probes are clinically available. It is expected that the combination of various general strategies should dramatically facilitate the process of imaging probe development. These translatable approaches include, but are not limited to, high-throughput technologies for the identification of ligands for specific disease biomarkers, reliable and site-specific conjugation chemistries for coupling reporting moieties (such as radionuclides and fluorescent molecules) to binding ligands, and techniques for rapid evaluation of the in vitro and in vivo properties of the resulting bioconjugates. Antibodies and their fragments traditionally have been used as 


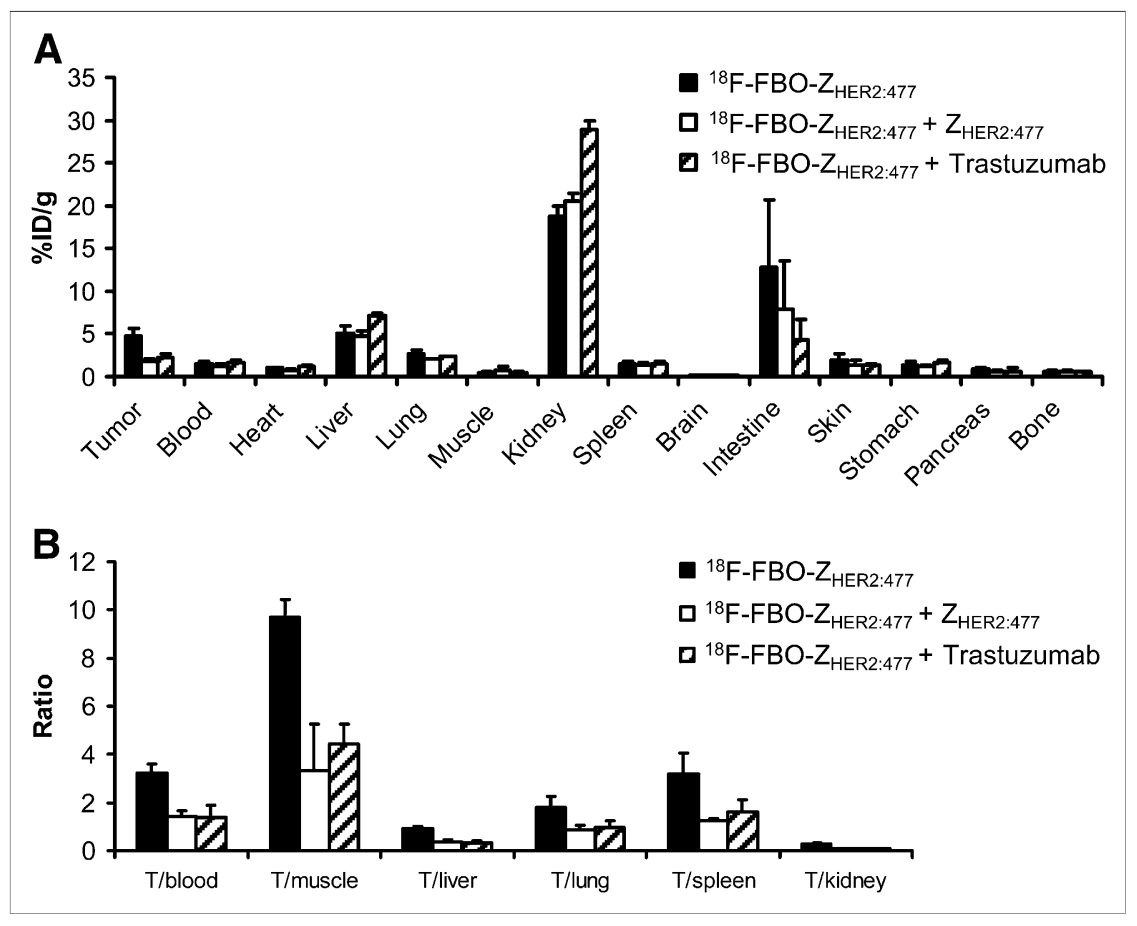

FIGURE 6. In vivo HER2 tumor-targeting specificity of ${ }^{18} \mathrm{~F}-\mathrm{FBO}-\mathrm{Z}_{\mathrm{HER} 2: 477}$. Onehour biodistribution results $(A)$ and tumor-to-normal tissue ratios (B) are shown for ${ }^{18} \mathrm{~F}-\mathrm{FBO}-\mathrm{Z}_{\mathrm{HER} 2: 477}$ with or without pretreatment with either $300 \mu \mathrm{g}$ of $Z_{\text {HER2:477 }}$ or $500 \mu \mathrm{g}$ of trastuzumab. ${ }^{18} \mathrm{~F}-\mathrm{FBO}-\mathrm{Z}_{\text {HER2:477 }}$ SKOV3 tumor (T) uptake was significantly inhibited by $\mathrm{Z}_{\text {HER2:477 }}$ or trastuzumab $(P<0.05)(n=3)$.

valuable platform molecules for imaging and therapeutic agent development. A vast number of antibodies against a variety of antigens can be easily generated by use of conventional hybridoma technology. Antibodies labeled with long-lived PET radioisotopes have been investigated and have been shown to have broad applications in tumor detection, tumor target validation, radiation dose estimation, and optimization and individualization of antibody-based therapies (24). However, the slow pharmacokinetic properties of antibodies makes them less than ideal as a targeting platform for PET probes, especially for ${ }^{18} \mathrm{~F}$-based imaging agents. More recently, many in vitro display technologies (phages, bacteria, yeasts, ribosomes, and messenger RNA) in conjunction with rational protein engineering have been used to construct nonimmunoglobulin protein libraries with a defined scaffold. The rapid progress of protein display technologies has led to the discovery of many novel small proteins and peptides with high affinity and specificity for a variety of molecular targets $(25,26)$. These proteins are superior sources for the development of biodrugs and molecular probes (27). Importantly, their relatively small size generally leads to fast clearance, rapid tumor accumulation, and relatively short in vivo biologic half-life (6-13), which potentially matches well the physical half-life of ${ }^{18} \mathrm{~F}$, one of the most widely available PET radioisotopes. We hypothesized that this small protein scaffold would have great potential for the development of novel PET probes for a variety of targets. Thus, Affibody molecules with a 3-helixbundle scaffold structure were selected for radiolabeling with ${ }^{18} \mathrm{~F}$ and evaluated in this work as a proof-of-concept study.

A strategy based on oxime chemistry has been developed for the radiofluorination of Affibody molecules. Site-specific labeling of a protein is critical to preserving the biologic activity of the biomolecule. A cysteine residue was engineered into the Affibody molecule $\mathrm{C}$ terminus, providing a thiol moiety to which site-selective chemistry could be applied. A bifunctional linker (Mal-AO) consisting of a thiol-reactive maleimide group and an aldehyde-reactive aminooxy group was prepared. It was then specifically conjugated to the Affibody molecules via the well-documented thiol-maleimide reaction, resulting in a protein with aminooxy functionality (Fig. 1). This aminooxy-functionalized protein could react efficiently and specifically with an aldehyde-functionalized ${ }^{18} \mathrm{~F}$-synthon, such as $4-{ }^{18} \mathrm{~F}$-FBA, under slightly acidic conditions, thereby forming a stable, nonreversible oxime linkage (22). Simultaneously, the acidic conditions avoided the potential reaction of the aldehyde with amine groups present on the Affibody molecules to form Schiff bases (Mohammad Namavari, unpublished data, March 2007). The aminooxy functionalization of the Affibody molecules allowed the opportunity for radiochemistry with fewer steps and thereby higher yield through a scheme that left the radiosynthesis step until the end of the procedure but still enabled selective conjugation. Only 2 radiosynthesis steps were involved in this procedure, and a nonoptimized radiochemical yield (decay corrected) of $13 \%-18 \%$ was achieved in a total preparation time of $100 \mathrm{~min}$. The radiochemical yield reported here was lower than that of the ${ }^{18} \mathrm{~F}$-labeled peptides $(60 \%-80 \%)$ reported by Poethko et al. (22), likely for the following reasons: the concentration of the aminooxy precursor $\left[\mathrm{Z}_{\mathrm{HER} 2: 477}-\mathrm{ONH}_{2}\right.$ or $\left.\left(\mathrm{Z}_{\mathrm{HER} 2: 477}\right)_{2}-\mathrm{ONH}_{2} ; 0.238 \mathrm{mmol} / \mathrm{L}\right]$ was lower than that of the aminooxy-peptide precursor $(0.5 \mathrm{mmol} / \mathrm{L})$, and the $\mathrm{pH}$ used for Affibody molecule radio- 


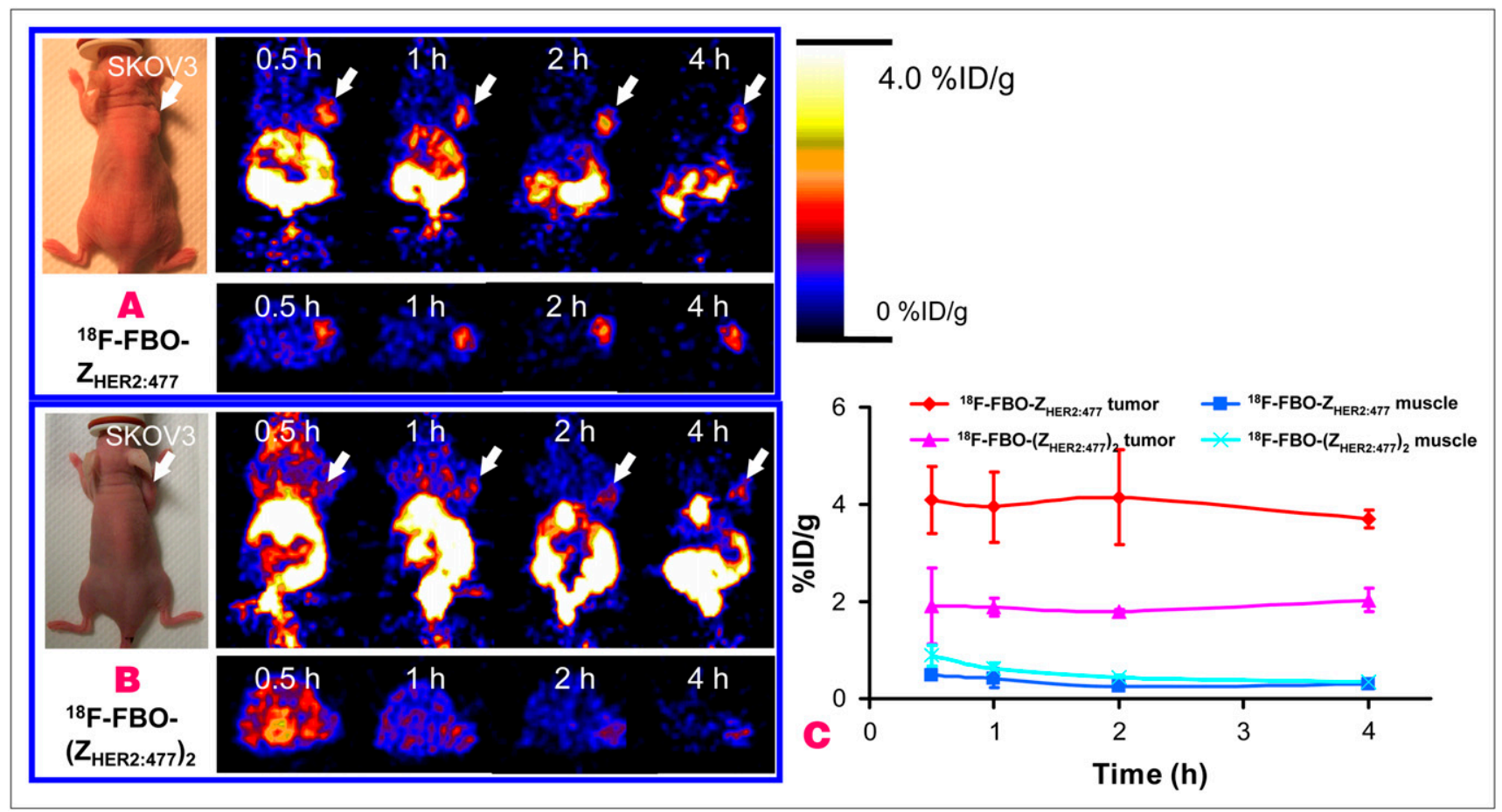

FIGURE 7. Decay-corrected coronal (top) and transaxial (bottom) small-animal PET images of nude mice bearing SKOV3 tumors on right shoulder at $0.5,1,2$, and $4 \mathrm{~h}$ after tail vein injection of ${ }^{18} \mathrm{~F}-\mathrm{FBO}-\mathrm{Z}_{\mathrm{HER} 2: 477}(\mathrm{~A})$ and ${ }^{18} \mathrm{~F}-\mathrm{FBO}-\left(\mathrm{Z}_{\mathrm{HER} 2: 477}\right)_{2}(\mathrm{~B})$. Arrows indicate locations of tumors. (C) Tumor and muscle time-activity curves derived from multiple-time-point small-animal PET images of mice bearing SKOV3 tumors. Data are shown as mean \pm SD \%ID/g $(n=3)$.

fluorination $(\mathrm{pH} 4)$ was higher than those found to be optimal for ${ }^{18} \mathrm{~F}$-peptides (pH 2-pH 3). Thus, further optimization of our current labeling procedure is under investigation and may result in a higher radiolabeling yield. Compared with an amine-reactive ${ }^{18} \mathrm{~F}$-synthon, such as $\mathrm{N}$-succinimidyl-4- ${ }^{18} \mathrm{~F}$-fluorobenzoate $\left({ }^{18} \mathrm{~F}-\mathrm{SFB}\right),{ }^{4}-{ }^{18} \mathrm{~F}-\mathrm{FBA}-$ aminooxy chemistry has some distinctive advantages. First, $4-{ }^{18} \mathrm{~F}-\mathrm{FBA}$-aminooxy chemistry provides a method for the site-specific radiofluorination of a protein, whereas ${ }^{18} \mathrm{~F}-\mathrm{SFB}$ can react with any lysine presenting in the protein, a property that may compromise the biologic activity of the protein. Second, ${ }^{18} \mathrm{~F}-\mathrm{SFB}$ labeling takes $173 \mathrm{~min}$ for the 4-step radiosynthesis of an ${ }^{18} \mathrm{~F}-\mathrm{SFB}$-labeled diabody. The overall decay-corrected radiochemical yield is only $1.4 \%$ (28). The strategy for the site-specific radiofluorination of an aminooxyfunctionalized protein with an aldehyde-functionalized ${ }^{18} \mathrm{~F}$ synthon developed in the present study has a relatively short radiosynthesis time and a moderate yield (100 $\mathrm{min} ; 13 \%-18 \%$ yield). It can be used for the ${ }^{18} \mathrm{~F}$ labeling of many other proteins and has potential for generating PET probes for clinical applications.

The biologic properties of ${ }^{18} \mathrm{~F}-\mathrm{FBO}-\mathrm{Z}_{\mathrm{HER} 2: 477}$ and ${ }^{18} \mathrm{~F}-$ FBO- $\left(\mathrm{Z}_{\mathrm{HER} 2: 477}\right)_{2}$ were evaluated by in vitro cell assays, biodistribution studies, and small-animal PET imaging studies. Both ${ }^{18} \mathrm{~F}-\mathrm{FBO}-\mathrm{Z}_{\mathrm{HER} 2: 477}$ and ${ }^{18} \mathrm{~F}-\mathrm{FBO}-\left(\mathrm{Z}_{\mathrm{HER} 2: 477}\right)_{2}$ showed significantly higher uptake in SKOV3 cells than $\mathrm{Z}_{\mathrm{HER} 2: 477}$, demonstrating their HER2-binding specificity in vitro. Furthermore, ${ }^{18} \mathrm{~F}-\mathrm{FBO}-\mathrm{Z}_{\mathrm{HER} 2: 477}$ showed lower cell uptake than ${ }^{18} \mathrm{~F}-\mathrm{FBO}-\left(\mathrm{Z}_{\mathrm{HER} 2: 477}\right)_{2}$. This result was likely caused by the higher HER2-binding affinity of ${ }^{18} \mathrm{~F}-\mathrm{FBO}-\left(\mathrm{Z}_{\mathrm{HER} 2: 477}\right)_{2}$ ( 200 vs. $430 \mathrm{pM}$ ), indicating that multimerization of proteins does help to improve the binding affinity and cell uptake of ligands. This result was also consistent with other findings reported in the literature (29). However, nonspecific SKOV3 cell uptake was about 2-fold higher with ${ }^{18} \mathrm{~F}-\mathrm{FBO}-$ $\left(\mathrm{Z}_{\mathrm{HER} 2: 477}\right)_{2}$ than with ${ }^{18} \mathrm{~F}-\mathrm{FBO}-\mathrm{Z}_{\mathrm{HER} 2: 477}$ (Fig. 4).

Evaluation of both probes in mice demonstrated that ${ }^{18} \mathrm{~F}$ FBO-Z $Z_{\text {HER 2:477 }}$ is a promising agent for HER2 imaging. It rapidly localized in SKOV3 tumors and showed good tumor uptake, retention, and tumor-to-muscle ratios (Figs. 5 and 7). Even at $0.5 \mathrm{~h}$ after injection, SKOV3 tumors could be clearly visualized by PET, with good contrast. Higher levels of tumor-to-normal tissue contrast were achieved at later times, such as 1 and $3 \mathrm{~h}$. The in vivo HER2-binding specificity of ${ }^{18} \mathrm{~F}-\mathrm{FBO}-\mathrm{Z}_{\mathrm{HER} 2: 477}$ was also verified by the reduced SKOV3 tumor uptake obtained after pretreatment with a known HER2-targeting ligand $\left(\mathrm{Z}_{\mathrm{HER} 2}\right.$ or trastuzumab). Overall, the relatively easy preparation, favorable pharmacokinetic properties (such as rapid and high tumor uptake and good tumor contrast), and high specificity of ${ }^{18} \mathrm{~F}-\mathrm{FBO}-\mathrm{Z}_{\mathrm{HER} 2: 477}$ render it a useful agent for HER2 PET and related applications.

In contrast, although ${ }^{18} \mathrm{~F}-\mathrm{FBO}-\left(\mathrm{Z}_{\mathrm{HER} 2: 477}\right)_{2}$ showed higher affinity and cell uptake, its in vivo performance was quite poor: low tumor uptake and relatively high uptake in and slow clearance from normal tissues (such as blood, muscle, liver, 
lung, and spleen). These data suggest that the high binding affinity of a probe does not necessarily correspond to high tumor uptake in vivo. Multimerization of proteins may not always be an effective way to improve the tumor-targeting ability of a probe. Compared with a monomer, the larger size of a dimer may deter its tumor penetration ability and prolong its clearance. Moreover, the charge and polarity of a probe may also be altered by dimerization and thus affect its biodistribution substantially.

Many other radiohalogens $\left({ }^{125} \mathrm{I},{ }^{76 / 77 / 82} \mathrm{Br}\right.$, and $\left.{ }^{211} \mathrm{At}\right)$ and radiometals $\left({ }^{99 \mathrm{~m}} \mathrm{Tc},{ }^{111 / 114 \mathrm{~m}} \mathrm{In},{ }^{90} \mathrm{Y},{ }^{177} \mathrm{Lu}\right.$, and $\left.{ }^{68} \mathrm{Ga}\right)$ have been used to label Affibody molecules (5-15). Our data are generally consistent with the findings reported in these published studies. For example, it was reported that ${ }^{99 \mathrm{~m}} \mathrm{Tc}-$

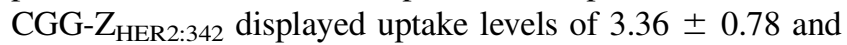
$4.23 \pm 1.03 \% \mathrm{ID} / \mathrm{g}$ in SKOV3 tumors at 1 and $4 \mathrm{~h}$ after injection, respectively, whereas the corresponding levels in the kidneys were $67.62 \pm 12.85$ and $58.84 \pm 8.76 \% \mathrm{ID} / \mathrm{g}$ (9). In the present study, the levels of uptake of ${ }^{18} \mathrm{~F}-\mathrm{FBO}-$ $\mathrm{Z}_{\mathrm{HER} 2: 477}$ in SKOV3 tumors at 1 and $3 \mathrm{~h}$ after injection were $4.77 \pm 0.88$ and $3.61 \pm 0.29 \% \mathrm{ID} / \mathrm{g}$, respectively, and the corresponding levels in the kidneys were $18.81 \pm 1.09$ and $7.37 \pm 0.85 \% \mathrm{ID} / \mathrm{g}$. Overall, radiolabeled Affibody molecules rapidly accumulated in tumors, with high uptake, but they typically showed high uptake in the kidneys as well. Good tumor-to-normal tissue ratios were achieved at early times after injection of the probes. It was also found that radiolabeled dimeric Affibody molecules showed poorer performance (tumor targeting and clearance) than monomeric Affibody molecules (8). In a previously published study, trastuzumab failed to block SKOV3 tumor uptake of ${ }^{177} \mathrm{Lu}-\mathrm{DOTA}-\mathrm{Z}_{\mathrm{HER} 2: 342-\text {-pep2 }}(6)$, whereas it blocked ${ }^{18} \mathrm{~F}$ FBO-Z $Z_{\text {HER2:477 }}$ tumor uptake in the present study. Although the cause of these observations is not completely clear, different routes of administration of the antibodies in these 2 studies (subcutaneous in the previously published study vs. tail vein injection in the present study) may be a factor. Moreover, different clones of anti-HER2 Affibody molecules used in these 2 studies may be another explanation.

\section{CONCLUSION}

A strategy for radiolabeling Affibody molecules has been successfully developed with oxime chemistry and antiHER2 Affibody molecules as a model platform. This strategy can potentially be translated to a universal approach for other applications. Moderate radiochemical yield and specific activity of the probes can be reliably obtained in a relatively short time. Biodistribution and small-animal PET imaging studies further demonstrated that ${ }^{18} \mathrm{~F}-\mathrm{FBO}-\mathrm{Z}_{\mathrm{HER} 2: 477}$ is a promising PET probe for imaging HER2 expression in living mice. The difference in performance between the monomer and the dimer demonstrated the importance of the fine balance between good affinity and size effects, which could influence penetration and profile properties. In addition, the combination of the high resolution, sensitivity, and quantitative ability of PET with the high specificity, selectivity, and fast pharmacokinetic profile of the Affibody protein scaffold make engineered protein-based PET an attractive strategy for further exploration.

\section{ACKNOWLEDGMENTS}

This work was supported, in part, by Medical Diagnostics, GE Healthcare, the National Cancer Institute (NCI), Small-Animal Imaging Resource Program (SAIRP) grant R24 CA93862, and NCI In Vivo Cellular Molecular Imaging Center (ICMIC) grant P50 CA114747. We thank Dr. David Dick for ${ }^{18} \mathrm{~F}$ production, Dr. Frederick T. Chin for modification of a GE TRACERlab FX-FN synthetic module for the radiosynthesis of ${ }^{4}{ }^{18} \mathrm{~F}-\mathrm{FBA}$, Dr. Joshua Hoerner and Hans Grade of GE Global Research for mass spectrometry analysis, and Dr. Alan Cuthbertson and Dr. Alex Gibson of GE Healthcare for their helpful suggestions and reviewing of the article.

\section{REFERENCES}

1. Meric-Bernstam F, Hung MC. Advances in targeting human epidermal growth factor receptor-2 signaling for cancer therapy. Clin Cancer Res. 2006;12:6326-6330.

2. Ferretti G, Felici A, Papaldo P, Fabi A, Cognetti F. HER2/neu role in breast cancer: from a prognostic foe to a predictive friend. Curr Opin Obstet Gynecol. 2007;19:56-62.

3. Smith-Jones PM, Solit DB, Akhurst T, Afroze F, Rosen N, Larson SM. Imaging the pharmacodynamics of HER2 degradation in response to Hsp90 inhibitors. Nat Biotechnol. 2004;22:701-706.

4. Tang Y, Wang J, Scollard DA, et al. Imaging of HER2/neu-positive BT-474 human breast cancer xenografts in athymic mice using ${ }^{111}$ In-trastuzumab (Herceptin) Fab fragments. Nucl Med Biol. 2005;32:51-58.

5. Baum R, Orlova A, Tolmachev V, Feldwisch J. Receptor PET/CT and SPECT using an Affibody molecule for targeting and molecular imaging of HER2positive cancer in animal xenografts and human breast cancer patients [abstract]. J Nucl Med. 2006;47(suppl):108P.

6. Orlova A, Tolmachev V, Pehrson R, et al. Synthetic Affibody molecules: a novel class of affinity ligands for molecular imaging of HER2-expressing malignant tumors. Cancer Res. 2007;67:2178-2186.

7. Tolmachev V, Orlova A, Pehrson R, et al. Radionuclide therapy of HER2positive microxenografts using a ${ }^{177} \mathrm{Lu}$-labeled HER2-specific Affibody molecule. Cancer Res. 2007;67:2773-2782.

8. Orlova A, Magnusson M, Eriksson TL, et al. Tumor imaging using a picomolar affinity HER2 binding Affibody molecule. Cancer Res. 2006;66:4339-4348.

9. Tran T, Engfeldt T, Orlova A, et al. In vivo evaluation of cysteine-based chelators for attachment of ${ }^{99 m} \mathrm{Tc}$ to tumor-targeting Affibody molecules. Bioconjug Chem. 2007;18:549-558.

10. Tolmachev V, Nilsson FY, Widström C, et al. ${ }^{111}$ In-Benzyl-DTPA-Z $Z_{\text {HER } 2: 342}$, an Affibody-based conjugate for in vivo imaging of HER2 expression in malignant tumors. J Nucl Med. 2006;47:846-853.

11. Orlova A, Nilsson FY, Wikman M, et al. Comparative in vivo evaluation of technetium and iodine labels on an anti-HER2 Affibody for single-photon imaging of HER2 expression in tumors. J Nucl Med. 2006;47:512-519.

12. Orlova A, Rosik D, Sandstrom M, Lundqvist H, Einarsson L, Tolmachev V. Evaluation of [(111/114m)In]CHX-A"-DTPA-Z(HER $2: 342)$, an Affibody ligand conjugate for targeting of HER2-expressing malignant tumors. $Q \mathrm{~J} \mathrm{Nucl} \mathrm{Med}$ Mol Imaging. 2007;51:1-10.

13. Fortin MA, Orlova A, Malmstrom PU, Tolmachev V. Labelling chemistry and characterization of $\left[{ }^{90} \mathrm{Y} /{ }^{177} \mathrm{Lu}\right]$-DOTA-ZHER $2: 342-3$ Affibody molecule, a candidate agent for locoregional treatment of urinary bladder carcinoma. Int $\mathrm{J} \mathrm{Mol}$ Med. 2007;19:285-291.

14. Mume E, Orlova A, Larsson B, et al. Evaluation of ((4-hydroxyphenyl)ethyl) maleimide for site-specific radiobromination of anti-HER2 Affibody. Bioconjug Chem. 2005;16:1547-1555.

15. Steffen AC, Almqvist Y, Chyan MK, et al. Biodistribution of ${ }^{211}$ At labeled HER-2 binding Affibody molecules in mice. Oncol Rep. 2007;17:1141-1147. 
16. Artemov D, Mori N, Ravi R, Bhujwalla ZM. Magnetic resonance molecular imaging of the HER-2/neu receptor. Cancer Res. 2003;63:2723-2727.

17. Hilger I, Leistner Y, Berndt A, et al. Near-infrared fluorescence imaging of HER2 protein over-expression in tumour cells. Eur Radiol. 2004;14:1124-1129.

18. Tada H, Higuchi H, Wanatabe TM, Ohuchi N. In vivo real-time tracking of single quantum dots conjugated with monoclonal anti-HER2 antibody in tumors of mice. Cancer Res. 2007;67:1138-1144.

19. Nilsson FY, Tolmachev V. Affibody molecules: new protein domains for molecular imaging and targeted tumor therapy. Curr Opin Drug Discov Devel. 2007;10:167-175.

20. Wikman M, Steffen AC, Gunneriusson E, et al. Selection and characterization of HER2/neu-binding Affibody ligands. Protein Eng Des Sel. 2004;17:455-462.

21. Okarvi SM. Recent progress in fluorine-18 labelled peptide radiopharmaceuticals. Eur J Nucl Med. 2001;28:929-938.

22. Poethko T, Schottelius M, Thumshirn G, et al. Two-step methodology for highyield routine radiohalogenation of peptides: ${ }^{18} \mathrm{~F}$-labeled RGD and octreotide analogs. J Nucl Med. 2004;45:892-902.
23. Cheng Z, Xiong Z, Subbarayan M, Chen X, Gambhir SS. ${ }^{64} \mathrm{Cu}-$ Labeled alphamelanocyte-stimulating hormone analog for microPET imaging of melanocortin 1 receptor expression. Bioconjug Chem. 2007;18:765-772.

24. Verel I, Visser GW, van Dongen GA. The promise of immuno-PET in radioimmunotherapy. J Nucl Med. 2005;46(suppl):164S-171S.

25. Rothe A, Hosse RJ, Power BE. In vitro display technologies reveal novel biopharmaceutics. FASEB J. 2006;20:1599-1610.

26. Uchiyama F, Tanaka Y, Minari Y, Tokui N. Designing scaffolds of peptides for phage display libraries. J Biosci Bioeng. 2005;99:448-456.

27. Ladner RC. Polypeptides from phage display: a superior source of in vivo imaging agents. Q J Nucl Med. 1999;43:119-124.

28. Cai W, Olafsen T, Zhang X, et al. PET imaging of colorectal cancer in xenograftbearing mice by use of an ${ }^{18} \mathrm{~F}$-labeled T84.66 anti-carcinoembryonic antigen diabody. J Nucl Med. 2007;48:304-310.

29. Cheng Z, Wu Y, Xiong Z, Gambhir SS, Chen X. Near-infrared fluorescent RGD peptides for optical imaging of integrin $\alpha_{\mathrm{v}} \beta_{3}$ expression in living mice. Bioconjug Chem. 2005;16:1433-1441. 